sciendo Zagreb International Review of Economics \& Business, Vol. 22, Special Conference Issue, pp. 1-14, 2019

(C) 2019 Faculty of Economics and Business, University of Zagreb and De Gruyter Open

All rights reserved. Printed in Croatia

ISSN 1331-5609; UDC: $33+65$

DOI: 10.2478 /zireb-2019-0001

CONFERENCE PAPER

\title{
Access to Finance - Experiences of SMEs in Croatia
}

\author{
Marko Kolaković* \\ Mladen Turuk* \\ Ivan Turčic *
}

\begin{abstract}
Access to finance for small and medium enterprises still represents one of the biggest problems that entrepreneurs face when launching their business or when they want to enhance their production capacities in other stages of the enterprise life cycle. Entrepreneurs generally use informal sources of financing when starting their business (3F: family, friends and fools) if they do not have other available sources of financing. There is a common classification in the literature that divides the sources of financing to: informal investors, debt financing, equity financing, government support programs and the entrepreneurs'own sources. The purpose of the survey conducted for this paper is to determine the sources of used finance of Croatian SMEs and the main problems that SMEs encountered while accessing finance. The second main goal of this article is to identify future needs for financing with potential financing problems that may occur. We gathered data from Croatian SMEs about the sources of funding used over the past three years and about the funding sources that they intend to use in the next three years. In last part of the paper we analyze the results from the survey and from that draw the implications for policy makers and market participants.
\end{abstract}

Keywords: access to finance; Croatian SMEs; financing SMEs; state grants; equity

JEL Classification: L26, G23, G32

\section{Introduction}

Access to capital and financing is extremely important for every enterprise. SMEs, and especially micro and small enterprises, face challenges when financing their entrepreneurial ventures, particularly during the initial stages of the enterprises' life

\footnotetext{
* Marko Kolaković, Mladen Turuk and Ivan Turčić are at Faculty of Economics and Business, University of Zagreb, Zagreb, Croatia.
} 
cycle. Cvijanović et al. (2008) point out that access to finance and cost-effective financing are essential assumptions for start-up, ongoing business, expansion and development of the enterprise. Also, the future growth, business sustainability, and success of each business depends heavily on the availability of capital and financing. Banks will always be more willing to extend lines of credit to large and medium-sized enterprises than to micro and small enterprises. Due to this fact, the government should act in order to help finance SMEs through state aid programs and various measures. The sector of small and medium-sized enterprises, which is further divided into micro, small and medium-sized enterprises, had a 99.7 percent share in the entire economy in 2017. Micro, small and medium-sized enterprises employed 73.2 percent of all employees in business enterprises in Croatia in 2017, and these figures indicate that the observed category is in fact the cornerstone of the Croatian economy (CEPOR 2018). The classification of enterprises in the Republic of Croatia is based on the European Commission recommendation on the definition of micro, small and medium-sized enterprises. In Croatia, the Act on Incentives for the Development of Small Economy (2016) provides the categories of micro, small and medium enterprises of small business, according to the size of the enterprise. The criteria chosen for the classification of business enterprises according to their size are the following: the average annual number of employees and the annual income realized in the previous year, or the balance sheet total if the enterprise is required to pay tax on profit or long-term assets if the enterprise is required to pay income tax. Table 1 provides more detailed criteria for classifying business enterprises.

Table 1: Classification of SME

\begin{tabular}{|l|c|c|c|c|}
\hline \multicolumn{1}{|c|}{ Company category } & Staff headcount & Turnover & or & Balance sheet total \\
\hline Medium-sized & $<250$ & $\leq € 50 \mathrm{~m}$ & $\leq € 43 \mathrm{~m}$ \\
\hline Small & $<50$ & $\leq € 10 \mathrm{~m}$ & $\leq € 10 \mathrm{~m}$ \\
\hline Micro & $<10$ & $\leq € 2 \mathrm{~m}$ & $\leq € 2 \mathrm{~m}$ \\
\hline
\end{tabular}

Source: European Commission - COMMISSION RECOMMENDATION of 6 May 2003 concerning the definition of micro, small and medium-sized enterprises

In 2013, the World Bank conducted a research in Croatia where enterprises had to choose the top business environment obstacle for firms. Following "tax rates", selected by 28.3 percent of enterprises, the second largest obstacle was "access to finance" with 21.6 percent. It is evident that enterprises in Croatia perceive access to finance as one of the biggest problems. For this very reason, the purpose of the research conducted for this paper was to collect information on access to finance and financing sources used by enterprises during the past three years, as well as information on financing sources planned for the next three years. The objectives of the research were the following: a) identify the sources of financing the enterprise used and their experience and b) determine the future needs for financing with potential financing 
problems. The survey encompassed 1000 enterprises from the Croatian business entity register, selected by the random sample method, and the enterprises were chosen in proportion to the number of enterprises of each individual industry in the total number of enterprises in the Croatian economy according to the Statistical classification of economic activities in the European Community - NACE (in Croatian language: Nacionalna klasifikacija djelatnosti - NKD) for each industry. Only enterprise with fewer than 250 employees were contacted, thus the research was carried out on micro, small and medium-sized enterprises. A total of 50 enterprises, of the 1000 contacted, responded, resulting in a return rate of 5 percent. The survey contained 18 questions. The introductory section referred to general business information. The second part of the survey referred to the sources of financing that the enterprise used over the past three years, focusing on the lack of access to finance. The last part of the survey referred to future financing needs: expected amount, source of financing, use of financing, etc. Some questions presented a possibility of choosing multiple answers so, in certain cases, the possible amount of answers was higher than 50 .

\section{Past Experience in Raising Finance of Croatian SMEs}

A total of 50 enterprises participated in the survey: 54 percent micro, 36 percent small and 10 percent medium-sized enterprises. With regards to industry, the construction industry, manufacturing industry, wholesale and retail, and information and communication activities were the most represented. The listed industries have a high share of enterprises in the total number of Croatian business enterprises.

During the last 3 years, 58 percent of the surveyed enterprises tried to access additional sources of financing ( 29 out of 50 enterprises). Table 2 shows the most frequently used sources of enterprise financing. Most enterprises tried to obtain more than one source of financing, which means the number of responses is greater than 29. Bank loan/mortgage/overdraft were the most commonly used sources of financing with 68.9 percent. The reason for this is that an enterprise can use its overdraft to quickly obtain a limited amount of funds when there is an immediate need, but on the other hand, this represents one of the most expensive forms of financing. According to Škrtić and Mikić (2011), bank loans are the most commonly used financing sources for enterprises. Banks require collateral for issued loans, most often in the form of assets. Many enterprises, especially at the beginning of their entrepreneurial ventures and in the early stages of development, do not have enough assets, i.e. collateral, for obtaining loans. If enterprises in the later phases of development manage to get a loan, the bank will be interested in financial statements from previous years, but also projections for the period in which the loan is taken. The cash flow statement is the most important financial statement for the bank, as it shows if the enterprise can generate a cash flow that 
makes the loan repayment possible. Leach \& Melicher (2009) emphasize that commercial banks prefer lending to established firms with two years of financial statements.

Table 2: Sources of finance/equity of Croatian SMEs

\begin{tabular}{|c|c|c|}
\hline Source & No. of enterprises & $\%$ \\
\hline Family and friends & 8 & 27.6 \\
\hline State grants & 15 & 51.7 \\
\hline Leasing & 15 & 51.7 \\
\hline Bank loan/mortgage/overdraft & 20 & 68.9 \\
\hline Other private investors & 2 & 6.7 \\
\hline Venture capital funds & 1 & 3.4 \\
\hline Other & 0 & 0 \\
\hline
\end{tabular}

Source: Authors

State grants, along with leasing, were the second most commonly used source of financing with 51.7 percent. This data shows that a significant share of Croatian enterprises relies on the state and government to finance their entrepreneurial venture. Of the 21 enterprises that applied for state grants, 28.5 percent failed to procure the funds they wanted. State grants therefore represent the least successful financing source for enterprises. Various state financing programs organized by state and regional bodies and backed by state budget funds and European Union funds can greatly help enterprises in financing their entrepreneurial venture. Entrepreneurs are expected to meet certain requirements, for example, proper conducting of business, a written business plan and business development strategy, certain production capacity, and so on. A portion of entrepreneurs do not fulfill these requirements and therefore are not successful when applying for this type of financing. Limited funds available, strong competition in the form of other enterprises that apply for tenders and the slow nature of the selection process and the payment of funds are the most common problems that arise in this type of financing.

Family and friends were used by 27.6 percent of the enterprises, and these are the sources that enterprises use most often during the initial phase of their life cycle, as most other sources are unavailable to them. Only a small percentage of enterprises used equity financing, venture capital, and other private capital, and this type of financing is not common in the Croatian economy. Cumming and Johan (2014) define venture capital funds as financial intermediaries between institutional investors from which they raise funds and high-growth and high-tech enterprises that are most often the beneficiaries of such financing. These funds are willing to invest in enterprises they expect to provide a high return on investment, and receive a share in equity and potential control over the enterprise.

Table 3 shows the number of enterprises according to the life cycle of the enterprise that tried or succeeded in obtaining all of the requested funding. Enterprises 
could choose between the following life cycle stages: start-up, development phase, steadily growing, considerable expansion, consistent sales but not growing, or decreasing sales. With regards to the enterprises' life-cycle, the surveyed enterprises were mostly steadily growing (56\%), followed by the "consistent sales but not growing" (20\%) phase. 10 percent of enterprises were in their development phase, while decreasing sales were reported by 6 percent of the surveyed enterprises. The smallest number of enterprises surveyed stated they were in the "start-up" or "considerable expansion" phase ( 2 percent per each stage). Almost 3/4 of the enterprises that tried to source financing have managed to do so in the requested amount. The percentage of success varies from 0 to 100 percent depending on the development stage of the enterprise. The most problems with the percentage of success in acquiring financing occurred in the development phase, where no enterprise managed to obtain the requested amount. Such a result could be assumed beforehand, as enterprises in the initial stages of business development are new on the market and lack sufficient production capacities and investors do not believe it is prudent to invest in them. All of the enterprises that were in the "considerable expansion" and "decreasing sales" phase have managed to obtain the desired funds. Slightly above the average of all enterprises that attempted to obtain funds (72.4 percent) are the enterprises that were past the initial phase of development and were in the "steadily growing" phase (77.7 percent) and the "consistent sales but not growing" phase (75 percent). Given the presented data, it can be concluded that enterprises at later stages of development have easier access to finance, which can be expected.

Table 3: Croatian SMEs that attempted to raise, or raised finance/equity by development stage

\begin{tabular}{|c|c|c|c|c|}
\hline Development stage & $\begin{array}{c}\text { No. of } \\
\text { enterprises }\end{array}$ & $\begin{array}{c}\text { No. of enterprises } \\
\text { that attempted to } \\
\text { raise finance/equity }\end{array}$ & $\begin{array}{c}\text { No. of firms that } \\
\text { raised all of the } \\
\text { finance required }\end{array}$ & $\begin{array}{c}\% \text { of firms that } \\
\text { raised all of the } \\
\text { finance required }\end{array}$ \\
\hline Start-up & 2 & 1 & 1 & 100 \\
\hline Development phase & 5 & 3 & 0 & 0 \\
\hline Steadily growing & 28 & 18 & 14 & 77.7 \\
\hline Considerable expansion & 2 & 2 & 2 & 100 \\
\hline Consistent sales but not growing & 10 & 4 & 3 & 75 \\
\hline Decreasing sales & 3 & 1 & 21 & 100 \\
\hline Total & 50 & 29 & & 72.4 \\
\hline
\end{tabular}

Source: Authors

Enterprises that have successfully raised the full required amount are shown in Table 4. Each enterprise had to specify the exact amount that was raised during the past 3 years, and the enterprises were then grouped into classes. In the lowest classes of $€ 0-€ 20,000$ and $€ 20,001-€ 50,000$, only 64 and 25 , respectively, percent of 
enterprises managed to raise funds and thus fall into the worst categories. The sources of financing used by these enterprises were mostly state grants, bank loan/mortgage/ overdraft, and family and fools. Although every second enterprise attempted to raise finance/equity in an amount up to $€ 50,000$, the enterprises were relatively unsuccessful in raising them, with state grants having the highest rate of unsuccessful financing.

Table 4: Enterprises that raised finance/equity by amount categories

\begin{tabular}{|c|c|c|c|}
\hline $\begin{array}{c}\text { Amount of the finance/ } \\
\text { equity required }\end{array}$ & $\begin{array}{c}\text { No. of } \\
\text { enterprises }\end{array}$ & $\begin{array}{c}\text { No. of firms that raised all of } \\
\text { the finance/equity required }\end{array}$ & $\begin{array}{c}\text { \% of firms that raised all of the } \\
\text { finance/equity required }\end{array}$ \\
\hline$€ 0-€ 20,000$ & 11 & 7 & 64 \\
\hline$€ 20,001-€ 50,000$ & 4 & 1 & 25 \\
\hline$€ 50,001-€ 100,000$ & 7 & 7 & 100 \\
\hline$€ 100,001-€ 500,000$ & 2 & 2 & 100 \\
\hline$€ 500,001-€ 1,500,000$ & 3 & 2 & 67 \\
\hline$€ 1,500,000+$ & 2 & 2 & 100 \\
\hline Total & 29 & 21 & 72.4 \\
\hline
\end{tabular}

Source: Authors

The amount of finance/equity attempted to be raised by Croatian micro, small and medium enterprise by their development stage categories is presented in Table 5. Of the surveyed enterprises that were in the development phase, 67 percent tried to raise up to $€ 20,000$. According to the table below, 55.5 percent of steadily growing enterprises tried to raise up to $€ 50,000$, and 27.3 percent of these enterprises tried to raise $€ 50,000$ to $€ 500,000$. Ultimately, this means that almost 85 percent of the enterprises at this stage asked for financing up to $€ 500,000$. The surveyed enterprises that were in the "consistent sales but not growing" phase did not try to raise more than $€ 100,000$.

Table 5: Amount of finance/equity attempted to be raised by Croatian SMEs by development stage categories

\begin{tabular}{|c|c|c|c|c|c|c|c|}
\hline Development stage & $\begin{array}{c}€ 0- \\
€ 20,000\end{array}$ & $\begin{array}{c}€ 20,001- \\
€ 50,000\end{array}$ & $\begin{array}{c}€ 50,001- \\
€ 100,000\end{array}$ & $\begin{array}{c}€ 100,001- \\
€ 500,000\end{array}$ & $\begin{array}{c}€ 500,001- \\
€ 1,500,000\end{array}$ & $€ 1,500,000+$ & $\Sigma$ \\
\hline Start-up & 1 & 0 & 0 & 0 & 0 & 0 & 1 \\
\hline Development phase & 2 & 0 & 0 & 0 & 1 & 0 & 3 \\
\hline Steadily growing & 6 & 4 & 3 & 2 & 1 & 2 & 18 \\
\hline Considerable expansion & 0 & 0 & 1 & 0 & 1 & 0 & 2 \\
\hline $\begin{array}{c}\text { Consistent sales but not } \\
\text { growing }\end{array}$ & 2 & 0 & 2 & 0 & 0 & 0 & 4 \\
\hline $\begin{array}{c}\text { Decreasing } \\
\text { Sales }\end{array}$ & 0 & 0 & 1 & 0 & 0 & 0 & 1 \\
\hline $\begin{array}{c}\text { Total number of } \\
\text { enterprises that attempted } \\
\text { to raise finance/equity }\end{array}$ & 11 & 4 & 7 & 2 & 3 & 2 & 29 \\
\hline
\end{tabular}

Source: Authors 
Out of the 29 surveyed enterprises, 8 (27.6 percent) failed to raise the requested amount of financing. These enterprises were asked to specify how the lack of financing impacted their business. The answers are presented in Table 6, note that the enterprises could choose more than one answer. The most reported negative impact due to failure to raise financing was "unable to update technology/equipment" that 62.5 percent of enterprises experienced. The next two most common problems were "unable to hire new employees" and "working capital and cash flow constraints" with 50 percent each. These were followed by "unable to finance purchase of land and buildings" with 37.5 percent. "unable to finance R \& D" and "unable to invest in marketing and advertising" were a problem faced by 25 percent of enterprises. The problem of dependency on bank finance was experienced by 12.5 percent of enterprises.

Enterprises were then asked to list the reasons they think best explain their failure to raise financing. 37.5 percent of the enterprises stated that "insufficient collateral or guarantee" was the most important reason why they failed to raise the required funds. The enterprises stated that the second most important reason for not raising financing was "lack of track records", with 25 percent. The other reasons mentioned by enterprises in a smaller percentage include procedural error, lack of recommendations from the ruling party, and dissatisfaction with the existing entrepreneurial ecosystem. None of the enterprises stated an unclear business plan, being uninteresting for investors and enterprise declared high-risk as reasons for being unable to raise all the finance/equity required.

Table 6: Effects of finance/equity shortage of Croatian SMEs

\begin{tabular}{|c|c|c|}
\hline Consequences & No. of enterprises & $\%$ \\
\hline Unable to finance R\&D & 2 & 62.5 \\
\hline Unable to update technology/equipment & 5 & 37.5 \\
\hline Unable to finance purchase of land and buildings & 3 & 25 \\
\hline Unable to invest in marketing and advertising & 2 & 50 \\
\hline Unable to hire new employees & 4 & 50 \\
\hline Working capital and cash flow constraints & 4 & 12.5 \\
\hline Dependent on bank finance & 1 & 0 \\
\hline Other & 8 & - \\
\hline Total number of enterprises & & \\
\hline
\end{tabular}

Source: Authors 


\section{Present and Future Financing Needs}

In the second part of the survey, the enterprises were asked to state their additional current and future financing needs for the next 3 years. Out of the 50 surveyed enterprises, 34 (68 percent) said they intend to apply for additional funds. Interestingly, almost 80 percent of enterprises that have stated they tried to obtain additional sources of financing during the past 3 years, are in need of financing for the next 3 years (23 enterprises). The share of enterprises that did not apply in the previous period but planned to apply in the next 3 years is 32 percent (11 enterprises).

Table 7 contains the expected amounts of financing needed for Croatian micro, small and medium enterprises for the next three years. 32 percent of the enterprises stated they wanted to raise between $€ 20,001-€ 50,000$, which is also the highest percentage. This mentioned category with the $€ 0-€ 20,000$ class cumulatively represents 50 percent of all financial needs.

Table 7: Expected amount of finance/equity requirements in the next three years

\begin{tabular}{|c|c|c|c|}
\hline $\begin{array}{c}\text { Amount of the finance/equity } \\
\text { requirement in the next 3 years }\end{array}$ & No. of enterprises & $\begin{array}{c}\text { \% of firms indicating a } \\
\text { requirement in the next } \\
\text { three years }\end{array}$ & $\begin{array}{c}\text { Cumulative } \\
\text { percentage }\end{array}$ \\
\hline$€ 0-€ 20,000$ & 6 & 18 & 18 \\
\hline$€ 20,001-€ 50,000$ & 11 & 32 & 50 \\
\hline$€ 50,001-€ 100,000$ & 6 & 18 & 68 \\
\hline$€ 500,001-€ 1,500,000$ & 7 & 20 & 97 \\
\hline$€ 1,500,000+$ & 3 & 9 & 100 \\
\hline Total & 1 & 3 & - \\
\hline
\end{tabular}

Source: Authors

An analysis of the expected amount of finance/equity requirements that Croatian SMEs will attempt to raise and the development phase of the surveyed enterprises was conducted. The results are presented in Table 8. Of the enterprises that are in the development phase, 80 percent think that they will need to raise up to $€ 50,000$ from additional sources of financing in the next three years. As much as 48 percent of the steadily growing enterprises wish to raise up to $€ 50,000$ in additional financing over the next three years, and with 38 percent of enterprises that want to apply for an additional $€ 50,000-€ 500,000$, this means that 86 percent of these enterprises intend to obtain up to $€ 500,000$. This piece of data suggests that there was no deviation in comparison to the period of 3 years ago (see Table 5). 
Table 8: Expected amount of finance/equity requirements that Croatian SMEs will attempt to raise by development stage categories in the next three years

\begin{tabular}{|c|c|c|c|c|c|c|c|}
\hline Development stage & $€ 0-€ 20,000$ & $\begin{array}{c}€ 20,001- \\
€ 50,000\end{array}$ & $\begin{array}{l}€ 50,001- \\
€ 100,000\end{array}$ & $\begin{array}{c}€ 100,001- \\
€ 500,000\end{array}$ & $\begin{array}{l}€ 500,001- \\
€ 1,500,000\end{array}$ & $€ 1,500,000+$ & $\Sigma$ \\
\hline Start-up & 0 & 0 & 0 & 0 & 0 & 0 & 0 \\
\hline $\begin{array}{l}\text { Development } \\
\text { phase }\end{array}$ & 1 & 3 & 0 & 1 & 0 & 0 & 5 \\
\hline Steadily growing & 3 & 7 & 3 & 5 & 2 & 1 & 21 \\
\hline $\begin{array}{c}\text { Considerable } \\
\text { expansion }\end{array}$ & 0 & 0 & 0 & 0 & 1 & 0 & 1 \\
\hline $\begin{array}{l}\text { Consistent sales } \\
\text { but not growing }\end{array}$ & 1 & 1 & 3 & 1 & 0 & 0 & 6 \\
\hline $\begin{array}{l}\text { Decreasing } \\
\text { sales }\end{array}$ & 1 & 0 & 0 & 0 & 0 & 0 & 1 \\
\hline $\begin{array}{l}\text { Total number of } \\
\text { enterprises that } \\
\text { will attempt to } \\
\text { raise finance/ } \\
\text { equity }\end{array}$ & 6 & 11 & 6 & 7 & 3 & 1 & 34 \\
\hline
\end{tabular}

Source: Authors

The enterprises were then asked whether it would be difficult for them to raise the required financing amount at this time, and whether it would be difficult to raise the required amount over the next 3 years (Table 8). While 76.5 percent of enterprises believe they will face financing problems today, the percentage for the next 3 years falls to 41.2 percent, which suggests that enterprises expect positive changes with regards to the availability of financing.

Table 9: Difficulty in raising finance/equity now and in the next three years

\begin{tabular}{|c|c|c|}
\hline Difficulties & No. of enterprises & $\%$ \\
\hline Yes - now & $26 / 34$ & 76.5 \\
\hline Yes - in the next 3 years & $14 / 34$ & 41.2 \\
\hline
\end{tabular}

Source: Authors

As for the period of the previous 3 years, enterprises had to state which sources of financing they expected to utilize in the next 3 years (Table 10). As can be seen from the table below, the responses are consistent with the answers for the previous period and there are no major or significant deviations. Most enterprises will try to raise the requested amounts from multiple sources. Bank loans still dominate as a source of financing with over 70 percent. Half of the enterprises will turn to the state and its support programs for entrepreneurs. HAMAG-BICRO and HBOR are the most relevant institutions in providing support to Croatian enterprises. 
Croatian Agency for SMEs, Innovations and Investments (HAMAG-BICRO) was founded with the aim of supporting the development of small and medium-sized enterprises, improving the innovation process and encouraging investments. The Agency's main objective is reflected in the strategic creation of a unique system that would provide support to entrepreneurs through all development stages of operation starting from research and development of an idea to commercialization and placement on the market. The Agency's activities include the promotion of establishment and development of small business entities, financing operation and development of small business entities by loans and guarantees issuing for approved loans by creditors as well as promotion of investments in small business. The Agency's also provides financial support to innovative and technology-oriented enterprises in Croatia by increasing commercialization of knowledge and awareness about the value of innovations, supporting the transfer of knowledge and technological solutions from the scientific sector to economy, promoting the establishment and development of technology infrastructure and participation in the creation and development of venture capital industry. HAMAG-BICRO offers enterprises the guarantees and collateral they need to be able to get loans from banks, and such measures greatly help businesses. Thanks to HAMAG, enterprises can make use of micro and small ESIF loans, ESIF guarantees and many other instruments.

Within the Croatian banking system, HBOR plays the role of a development and export bank established with the objective of financing the reconstruction and development of the Croatian economy. HBOR, in cooperation with business banks, offers a range of credit lines for various groups, such as start-ups, women entrepreneurs, young entrepreneurs, innovators and more. These credit lines grant entrepreneurs access to more favorable interest rates in comparison with the market interest rates. Other products and services available to entrepreneurs by HBOR are: bank export guarantees, performance related bank guarantees, export credit insurance, leasing for SME, documentary letter for credit and etc.

Almost half of the enterprises will ask for assistance from leasing enterprises, and they still represent a significant source of financial resources and equipment for enterprises. The most significant change occurred in the family $\&$ friend's category, with 17.6 percent of enterprises seeking their help, compared to 27.6 in the previous 3 years. This change should not be surprising because enterprises turn to family and friends mostly during the initial phase of their life cycle. During the latter development stages, enterprises will fulfill their capital requirements with more formal sources of financing. As far as equity financing is concerned, according to the survey conducted, this type of financing is still not acceptable to the vast majority of enterprises. Only 2.9 percent of enterprises will turn to other private investors, while none of the enterprises will seek financing from venture capital funds, as opposed to the past 3 years when over 10 percent of enterprises tried to secure financing through equity. 
Table 10: Expected sources of finance/equity requirements in the next 3 years

\begin{tabular}{|c|c|c|c|}
\hline Source & No. of enterprises & \% & \% of past sources \\
\hline Family and friends & 6 & 17.6 & 27.6 \\
\hline State grants & 17 & 50 & 51.7 \\
\hline Leasing & 16 & 47.1 & 51.7 \\
\hline Bank loan/mortgage/overdraft & 24 & 70.6 & 68.9 \\
\hline Other private investors & 1 & 2.9 & 6.7 \\
\hline Venture capital funds & 0 & 0 & 3.4 \\
\hline Other & 2 & 6 & 0 \\
\hline
\end{tabular}

Source: Authors

The penultimate question in the survey concerned the use of future raised funds. The enterprises could choose more than one answer. The answer "update technology/ equipment" was chosen by over 70 percent of enterprises. 55.9 percent of enterprises will hire new employees, with this answer being the second most common one. This is followed by the purchasing of land or buildings, i.e. investment into infrastructure, with slightly over 30 percent. A little under 30 percent of enterprises intend to use the raised finances for working capital and cash flow constraints. Around 20 percent of enterprises want to invest in marketing and advertising, while around 18 percent of enterprises will invest in research and development. None of the enterprises stated that they would invest the raised resources into shares.

Table 11: Use of future additional finance/equity Croatian SMEs

\begin{tabular}{|c|c|c|}
\hline Consequences & No. of enterprises & \% \\
\hline Finance R\&D & 6 & 17.6 \\
\hline Update technology/equipment & 24 & 70.6 \\
\hline Finance purchase of land and buildings & 11 & 32.4 \\
\hline Invest in marketing and advertising & 7 & 20.6 \\
\hline Hire new employees & 19 & 55.9 \\
\hline Working capital and cash flow constraints & 10 & 29.4 \\
\hline Investing in shares & 0 & 0 \\
\hline Other & 0 & 0 \\
\hline
\end{tabular}

Source: Authors

Table 12 reveals the most important limiting factor for obtaining the necessary financing according to the enterprises. As much as 41.2 percent of the surveyed enterprises believe that too much paperwork is the most significant limiting factor for obtaining the necessary funding. "Insufficient collateral or guarantee" and "Interest rates or price too high" account for the next two factors with high percentages (both limiting factors were selected by slightly more 20 percent of enterprises). Interestingly, one in ten enterprises believe that financing is not available at all. In contrast, 
2.9 percent of enterprises believe that there are no obstacles to raising the necessary amount. None of the surveyed enterprises considers reduced control over the enterprise as a limiting factor.

Table 12: Most important limiting factor to get finance/equity requirements in the next 3 years

\begin{tabular}{|c|c|c|}
\hline Limiting factor & No. of enterprises & \% \\
\hline There are no obstacles & 1 & 2.9 \\
\hline Insufficient collateral or guarantee & 7 & 20.6 \\
\hline Interest rates or price too high & 7 & 20.6 \\
\hline Reduced control over the enterprise & 0 & 0 \\
\hline Too much paperwork is involved & 14 & 41.2 \\
\hline Financing not available at all & 4 & 11.8 \\
\hline Other & 1 & 2.9 \\
\hline Total number of enterprises & 34 & 100 \\
\hline
\end{tabular}

Source: Authors

\section{Conslusion}

A total of 50 enterprises participated in the survey and during the last 3 years, 58 percent of the surveyed enterprises tried to access additional sources of financing. Most enterprises tried to obtain more than one source of financing. A bank loan/mortgage/overdraft with 68,9 percent and state grants with 51,7 percent each were most commonly used source of financing. State grants represent the least successful financing source for enterprises with 28.5 percent of failure. Only a small percentage of enterprises used equity financing, venture capital, and other private capital, and this type of financing is not common in the Croatian economy. With regards to the enterprises' life-cycle, the surveyed enterprises were mostly steadily growing (56\%), followed by the "consistent sales but not growing" (20\%) phase. Almost $3 / 4$ of the enterprises that tried to source financing have managed to do so in the requested amount. The most problems with the percentage of success in acquiring financing occurred in the development phase, where no enterprise managed to obtain the requested amount. Such a result could be assumed beforehand, as enterprises in the initial stages of business development are new on the market and lack sufficient production capacities and investors do not believe it is prudent to invest in them. Based on conducted survey, it can be concluded that enterprises at later stages of development have easier access to finance. Although every second enterprise attempted to raise finance/equity in an amount up to $€ 50,000$, the enterprises were relatively unsuccessful in raising them, with state grants having the highest rate of unsuccessful financing. 
Enterprises that failed to raise the requested amount of financing specify how the lack of financing impacted their business. The three most reported negative impacts due to failure to raise financing were: a) "unable to update technology/equipment" that 62.5 percent of enterprises experienced; b) "unable to hire new employees" and "working capital and cash flow constraints" with 50 percent each. According to surveys answers "insufficient collateral or guarantee" (37.5 percent) and "lack of track records" (25 percent) were the main reasons why they failed to raise the required funds.

In the second part of the survey, the enterprises were asked to state their additional current and future financing needs for the next 3 years. Out of the 50 surveyed enterprises, 34 (68 percent) said they intend to apply for additional funds. Interestingly, almost 80 percent of enterprises that have stated they tried to obtain additional sources of financing during the past 3 years, are in need of financing for the next 3 years (23 enterprises). The share of enterprises that did not apply in the previous period but planned to apply in the next 3 years is 32 percent (11 enterprises). While 76.5 percent of enterprises believe they will face financing problems today, the percentage for the next 3 years falls to 41.2 percent, which suggests that enterprises expect positive changes with regards to the availability of financing. Enterprises had to state which sources of financing they expected to utilize in the next 3 years and the amount. The responses were consistent with the answers for the previous period and there were no major or significant deviations. With expected additional finance, 70 percent of enterprises plan to update technology/equipment and 55.9 percent of enterprises intent to hire new employees. This is followed by the purchasing of land or buildings, i.e. investment into infrastructure, with a little over 30 percent. The most important limiting factor for obtaining the necessary financing according to the surveyed enterprises is "too much paperwork is involved" with 41.2 percent. "Insufficient collateral or guarantee" and "Interest rates or price too high" account for the next two factors with high percentages (both limiting factors were selected by slightly more 20 percent of enterprises). Interestingly, one in ten companies believe that financing is not available at all.

Insufficient collateral or guarantee is the reason why so many enterprises do not have access to finance. The government is trying to overcome this problem with various guarantee lines. State grants are facing the problems regarded to limited funds available and the slow nature of the selection process and the payment of funds. Banks and other state institutions should speed up the process of applying for credit lines and reduce paperwork involved. 


\section{REFERENCES}

CEPOR. (2018) Small and Medium Enterprises Report - Croatia 2018 including the results of GEMGlobal Entrepreneurship Monitor research for Croatia for 2017. Retrieved from http://www. cepor.hr/wp-content/uploads/2015/03/SME-report-2018-HR.pdf

Croatian Agency for SMEs, Innovations and Investments (HAMAG-BICRO). https://hamagbicro.hr/

Croatian Bank for Reconstruction and Development. http://www.hbor.hr/

Cumming, D. \&. Johan, S.A. (2014). Venture Capital and Private Equity Contracting. An International Perspective. London, Waltham: Elsevier

Cvijanović, V., Marović, M. \& Sruk. B. (2008). Financiranje malih i srednjih poduzeća. Zagreb: Bizona press d.o.o. \& HVCA

European Commission. (2003). COMMISSION RECOMMENDATION of 6 May 2003 concerning the definition of micro, small and medium-sized enterprises. Brussels: European Commission. Retrieved from https://eur-lex.europa.eu/legal-content/EN/TXT/PDF/?uri=CELEX:32003H0361\&from=EN

Leach, C. \& Melicher, R. W. (2009). Entrepreneurial Finance. Mason: South-Western Publishing Co

Narodne novine (2016). Act on Incentives for the Development of Small Economy, consolidated text of the act, official gazette "Narodne novine" nos. 29/02, 63/07, 53/12, 56/13, 121/16. Retrieved from https://www.zakon.hr/z/527/Zakon-o-poticanju-razvoja-malog-gospodarstva

Škrtić, M. \& Mikić, M. (2006). Poduzetništvo. Zagreb: Sinergija.

The World Bank (2013). Enterprise surveys - Croatia. Retrieved from http://www.enterprisesurveys. org/data/exploreeconomies/2013/croatia 